ROZDZIAŁ 4

\title{
Prawne uwarunkowania rewitalizacji w Polsce
}

Rewitalizacja miast jest procesem kompleksowym. W wielu krajach Europy Zachodniej prowadzona jest na podstawie odpowiednich regulacji prawnych, w których przewidziano także ułatwienia finansowe sprzyjające temu procesowi. Działania związane $\mathrm{z}$ rewitalizacją są zarządzane $\mathrm{w}$ tych krajach przez sektor publiczny oraz współfinansowane $\mathrm{w}$ istotnym stopniu $\mathrm{z}$ budżetów państwowych czy regionalnych. Kraje te korzystają z instrumentów urbanistyki operacyjnej, takich jak tworzenie stref sanacji i stref modernizacji (niemieckie - Sanierungsgebiet, angielskie - revitalization areas oraz conservation areas, francuskie - Operations Programme d'Amelioration de l'Habitat - OPAH) ${ }^{1}$, co przyniosło pozytywne rezultaty $\mathrm{w}$ odniesieniu do przekształceń i odnowy staromiejskich dzielnic mieszkaniowych.

W Polsce nie ma do tej pory tego rodzaju regulacji - brak ustawy o rewitalizacji lub jednoznacznego włączenia problematyki rewitalizacji w inne ustawy, przede wszystkim ustawę o planowaniu i zagospodarowaniu przestrzennym - w istotnym stopniu przyczynia się do tego, iż proces rewitalizacji nie nabrał $\mathrm{w}$ naszym kraju właściwego tempa i rozmiarów. Tym niemniej, wiele samorządów terytorialnych miast polskich opracowuje programy rewitalizacyjne i pomimo trudności organizacyjnych i finansowych przystępuje do ich realizacji ${ }^{2}$.

Niekorzystny wpływ na kształtowanie polityki rewitalizacyjnej w skali krajowej miało również prawo budowlane, dające po 1990 r. możliwość znacznego uproszczenia procedur prowadzących do realizacji inwestycji na terenach dotychczas niezagospodarowanych (greenfields), a nie oferując gminom skutecznych instrumentów zarządzania programami rewitalizacji i restrukturyzacji obszarów zdegradowanych (brownfields). Sytuacja ta doprowadziła do żywiołowego rozrostu powierzchniowego miast w strefach peryferyjnych, gdzie koncentrowało się nowe budownictwo mieszkaniowe i komercyjne centra

\footnotetext{
${ }^{1}$ E. Zawadzki, Analiza funkcjonujacych programów modernizacyjnych miejskich zasobów mieszkaniowych i użyteczności publicznej, Biuro Studiów i Ekspertyz, Raport nr 164, 1999.

${ }^{2}$ J. J. Parysek, Miasta polskie na przełomie XX i XXI wieku. Rozwój i przekształcenia strukturalne, Poznań 2005.
} 
handlowe, kosztem zapaści stref śródmiejskich, z pogarszającymi się warunkami mieszkaniowymi i zjawiskiem ubytku liczby ludności ${ }^{3}$.

Jak pisze w opracowaniu dotyczącym rewitalizacji miast polskich Alina Muzioł-Wencławowicz,

Miasta w Polsce są samotnymi długodystansowcami w grze o rewitalizację. Same inicjowały programy, dostosowywały je do swoich możliwości. Administracja rządowa wykorzystała zapowiedź alokacji środków funduszy strukturalnych UE na finansowanie projektów rewitalizacyjnych do uzasadnienia własnej pasywnej postawy wobec problemów rewitalizacji miast. Skala dofinansowania unijnego, jak i jego zakresy nie rozwiązują problemu wspierania rewitalizacji. Programy rządowe na rzecz rewitalizacji, obok istotnego czynnika bezpośredniego wsparcia organizacyjnego i finansowego, stanowią też swego rodzaju gwarancję dla sektora prywatnego, uwiarygodniają wieloletnie programy przekształceń struktur śródmiejskich.

O ile specjaliści spierają się o szczegółowe rozwiązania w definiowaniu instrumentów potrzebnych dla rozwoju rewitalizacji, o tyle ,poza dyskusją pozostaje twierdzenie, że nie dysponujemy specjalnymi instrumentami prawnymi, urbanistycznymi, finansowymi dla rewitalizacji [...]. Szczególne problemy nastręcza brak instrumentów urbanistyki operacyjnej oraz niedobór środków finansowych na prowadzenie kompleksowej rewitalizacji”, .

\subsection{Rewitalizacja a obowiązujące regulacje prawne}

Programy rewitalizacji są programami na rzecz rozwoju lokalnego i stanowią jeden z elementów strategicznej polityki rozwoju gmin.

Miejskie/lokalne programy rewitalizacji opracowywane w latach 20042006 bazowały - w sytuacji braku uregulowań prawnych w postaci ustawy o rewitalizacji - na wskazaniach zawartych w dokumentach na poziomie krajowym, związanych z absorpcją i wdrażaniem środków funduszy strukturalnych Unii Europejskiej. W poprzednim okresie planowania UE był to dokument strategiczny: Zintegrowany Program Operacyjny Rozwoju Regionalnego ZPORR 2004-2006, jak i opracowania służące jego wdrażaniu, o charakterze informacji i przewodników dla potencjalnych beneficjentów: Uzupetnienie Zintegrowanego Programu Rozwoju Regionalnego ZPORR 2004-2006 oraz Przewodnik dotyczqcy kryteriów planowania oraz projektami dotyczacymi rewitalizacji zdegradowanych obszarów miejskich, poprzemysłowych i powojskowych w ramach Zintegrowanego Programu Operacyjnego Rozwoju Regionalnego, finansowanego ze środków Funduszy Strukturalnych. W bieżącej siedmiolatce 2007-2013 zakres działań dotyczących rewitalizacji określany jest

${ }^{3}$ A. Billert, Odbudowa starych miast $w$ Polsce na tle rewitalizacji miast niemieckich, [w:] A. Billert (red.), Odbudowa i rewitalizacja starych miast $w$ Gtogowie, Lubaniu, Polkowicach, Frankfurt (Oder), Görlitz i Kamenz, Lubań 2007, s. 15.

${ }^{4}$ A. Muzioł-Wencławowicz, Rewitalizacja dzielnic śródmiejskich, [w:] W. Jarczewski (red.), Przestrzenne aspekty rewitalizacji - śródmieścia, blokowiska, tereny poprzemystowe, pokolejowe $i$ powojskowe, seria: Rewitalizacja Miast Polskich, tom 4, Kraków 2009, s. 80. 
na poziomie poszczególnych regionów w Regionalnych Programach Operacyjnych. Niektóre regiony (np. region małopolski) opracowały własne szczegółowe wytyczne, które mają służyć określeniu zakresu i struktury przygotowywanych programów rewitalizacji. Krótka prezentacja obecności problematyki rewitalizacji w strategicznych dokumentach na poziomie krajowym i regionalnym została przedstawiona w rozdz. 7 niniejszego opracowania.

W obecnie obowiązującym stanie prawnym, pewne elementy związane $\mathrm{z}$ procesami rewitalizacji są uwzględniane $\mathrm{w}$ ramach dokumentów planistycznych i strategicznych na poziomie gmin. Jak już wspomniano w poprzednich rozdziałach, zgodnie z ustawą o planowaniu i zagospodarowaniu przestrzennym, w Studium uwarunkowań i kierunków zagospodarowania przestrzennego wyznaczane są obszary „wymagające przekształceń, rehabilitacji lub rekultywacji”, natomiast w miejscowym planie zagospodarowania przestrzennego uwzględnia się w razie potrzeby „granice obszarów rehabilitacji istniejącej zabudowy i infrastruktury technicznej"5. Tematykę rewitalizacji uwzględnia zazwyczaj, w pośredni lub bezpośredni sposób, strategia rozwoju społeczno-gospodarczego gminy - program rewitalizacji musi być spójny ze strategią rozwoju gminy oraz innymi aktami prawa miejscowego oraz politykami określającymi kierunki rozwoju przestrzennego oraz społeczno-gospodarczego.

Program rewitalizacji powinien być przyjęty uchwałą rady gminy. Nie jest on dokumentem obligatoryjnym i gminy sporządzają go zazwyczaj w zakresie „,czysto funkcjonalnym, tzn. takim, który umożliwi ewentualnie skorzystanie ze środków unijnych, często bez kompleksowego ujęcia zagadnienia, zwłaszcza w części socjalno-społecznej i gospodarczej”.

Brak regulacji ustawowych w zakresie rewitalizacji skutkuje brakiem umocowania prawnego programów rewitalizacji. W odniesieniu do kwestii przestrzennych program taki może pełnić jedynie funkcję studiów i analiz do miejscowego planu zagospodarowania przestrzennego. Dopiero sporządzony na bazie programu rewitalizacji lub równolegle $\mathrm{z}$ nim miejscowy plan zagospodarowania przestrzennego umożliwia realizację przyjętych $\mathrm{w}$ programie rewitalizacji rozwiązań, jako dokument stanowiący prawo miejscowe. Takie rozwiązania były już stosowane dla umocowania prawnego działań związanych $\mathrm{z}$ rewitalizacją, np. w Bielsku-Białej ${ }^{7}$.

Należy zwrócić w tym miejscu uwagę na fakt, iż plan miejscowy jest często uważany za zbyt mało elastyczne narzędzie planistyczne w obszarach rewitali-

${ }^{5}$ Ustawa z dnia 27 marca 2003 r. o planowaniu i zagospodarowaniu przestrzennym (DzU 2003, art. 10, ust. 2 , pkt $14 \mathrm{i}$ art. 15 ust. 3 pkt 2).

${ }^{6} \mathrm{M}$. Węgłowski, Uwarunkowania prawne rewitalizacji miast, [w]: W. Rydzik (red.), Aspekty prawne $i$ organizacyjne zarzqdzania rewitalizacja, seria: Rewitalizacja Miast Polskich, t. 6, Kraków 2009, s. 44.

${ }^{7}$ Przykład rewitalizacji Starego Miasta w Bielsku-Białej przedstawiono w książce A. Wojnarowskiej Rewitalizacja zdegradowanych obszarów miejskich. Przykłady praktyczne, Łódź 2011. 
zacji. Okres opracowania i uchwalenia planu miejscowego lub zmian w planie (w wielu dużych miastach polskich jest to okres około dwóch lat) powoduje, że nie jest możliwe szybkie reagowanie na zmiany w potrzebach inwestorów oraz zmieniające się uwarunkowania w obszarze rewitalizacji.

Drugą kwestią jest zgłaszana przez środowisko urbanistów mała szczegółowość planu miejscowego, który nie daje wielu istotnych rozstrzygnięć, dotyczących kształtowania kompozycji urbanistycznej i zagospodarowania przestrzeni:

Dzisiaj, potrzeba zmian w podejściu do planowania rozwoju nowych i sanacji istniejących struktur miasta poprzez zdefiniowanie kompozycyjnych ram głównych składników jego przestrzeni, czyli wnętrz publicznych ulic i placów, jawi się jako podstawowe zadanie w zakresie urbanistyki. Niewystarczające narzędzie, jakim okazał się w ciągu minionych lat miejscowy plan zagospodarowania przestrzennego, pozbawiony podstawowych rozstrzygnięć o regułach kształtowania przestrzeni miasta w skali urbanistycznej (linie zabudowy, jej gabaryty i typologia), winno być uzupełnione projektami urbanistycznymi, dającymi odpowiedź na najpilniejsze potrzeby w zakresie sposobów porządkowania i rewitalizacji przestrzeni publicznych ${ }^{8}$.

Ponadto, istotnym mankamentem miejscowych planów zagospodarowania przestrzennego jest fakt, iż umożliwiają one - zgodnie z zapisami ustawy o planowaniu i zagospodarowaniu przestrzennym - przede wszystkim współdecydowanie o kształcie planu w zakresie poszczególnych działek prywatnych, natomiast nie wykorzystują szansy włączenia społeczności lokalnej w proces współtworzenia przestrzeni wspólnych i działania na rzecz interesu publicznego. W tej sytuacji, jak pisze Alina Muzioł-Wencławowicz ${ }^{9}$, następuje w zasadzie całkowita rozłączność rewitalizacji i planowania przestrzennego, i tylko niektóre miasta, jak Sopot czy Żyrardów, stosują plan miejscowy jako narzędzie dla uzyskania przełożenia założeń programu rewitalizacji na zapisy prawa miejscowego. Niektóre miasta prace nad programami rewitalizacji wykorzystują do realizacji zasady partycypacji społecznej w planowaniu przestrzennym, czego przykładem może być stworzony, przy daleko idącym zaangażowaniu społeczności lokalnej, plan miejscowy dla Śródki w Poznaniu.

Piotr Lorens zwraca uwagę na możliwość wykorzystania na potrzeby procesu rozwoju miejskiego, w tym procesu rewitalizacji, nowych instrumentów opracowań planistycznych o charakterze pozaustawowym. Pełnią one funkcję wspomagającą $\mathrm{w}$ tworzeniu polityki publicznej (w tym polityki przestrzennej miasta) oraz wskazują sposób realizacji procesów rozwoju miejskiego, określonych w przewidzianych ustawowo dokumentach planistycznych - studiach uwarunkowań i kierunków zagospodarowania przestrzennego oraz miejscowych planach zagospodarowania przestrzennego.

${ }^{8} \mathrm{~W}$. Wicher, Ulice - wzorce i standardy ksztaltowania przestrzeni dla komunikacji, [w:] Przestrzeń dla komunikacji w mieście, VIII Ogólnopolska III Międzynarodowa Konferencja Instytutu Projektowania Urbanistycznego, materiały konferencyjne, Kraków 2002, s. 353-362.

${ }^{9}$ A. Muzioł-Wencławowicz, Rewitalizacja dzielnic..., s. 58. 
Wyróżnia wiele typów i rodzajów tych dokumentów, w zależności od ich charakteru, zakresu terytorialnego, funkcji i zawartości, które można podzielić na trzy podstawowe grupy opracowań:

- Strategie i opracowania o charakterze wielosektorowym (czyli obejmującym nie tylko kwestie przestrzenne, ale także środowiskowe, społeczne, ekonomiczne, zagadnienia finansowe i budżetowe itp.), w tym:

- strategie rozwoju całych organizmów miejskich,

- strategie rozwoju poszczególnych dzielnic i/lub obszarów o kluczowym znaczeniu.

- Strategie rozwoju przestrzennego (czyli stanowiące uszczegółowienie strategii wielosektorowych dla zagadnień przestrzennych, łączące także kwestie natury ekonomicznej i środowiskowej - choć jedynie w zakresie niezbędnym z punktu widzenia przestrzeni miejskiej, w tym:

- strategie rozwoju przestrzennego całych organizmów miejskich, określających m.in. zasady prowadzenia polityki gruntowej i innych polityk branżowych,

- strategie rozwoju przestrzennego poszczególnych dzielnic jako całych organizmów,

- strategie rozwoju przestrzennego poszczególnych obszarów, szczegółowo określających niezbędne do podjęcia działania i ich sekwencje.

- Plany koordynacyjne dla przedsięwzięć urbanistycznych o charakterze zintegrowanym, w tym:

- koncepcje rozwoju poszczególnych dzielnic i obszarów,

- szczegółowe wytyczne do projektowania poszczególnych fragmentów przestrzeni miejskiej (tzw. design guidelines) ${ }^{10}$.

Zestaw wymienionych opracowań pozaustawowych obejmuje zarówno te stosowane w Polsce, jak i za granicą. W krajach Europy Zachodniej takie instrumenty faktycznie są wykorzystywane - jednym z nich jest plan docelowy, którego zakres i cele omówiono $\mathrm{w}$ rozdziale 3.6. Niektóre $\mathrm{z}$ miast polskich, realizujących programy rewitalizacji, starają się już tego rodzaju instrumenty stosować, jednak w bardzo ograniczonym jak dotychczas zakresie.

\subsection{Projekt ustawy o rewitalizacji}

Projekt Ustawy o rewitalizacji został opracowany w 2003 r. przez Urząd Mieszkalnictwa i Rozwoju Miast. Projekt ten powstał na bazie uzasadnionego przekonania, iż efektywne prowadzenie działań rewitalizacyjnych w miastach wymaga regulacji prawnej, która określi obowiązujące standardy w zakresie

${ }^{10}$ P. Lorens, Nowe instrumenty ksztaltowania przestrzeni publicznych miasta, [w:] M. Kochanowski (red.), Przestrzeń publiczna miasta postindustrialnego, Warszawa 2005, s. 202. 
opracowywania, realizacji i finansowania programów rewitalizacji, a także narzędzia kontroli i publicznego nadzoru, szczególnie w zakresie wykorzystania środków publicznych ${ }^{11}$.

W projekcie rewitalizację zdefiniowano jako działanie ukierunkowane na rozwój społeczno-gospodarczy i podniesienie jakości życia społeczności lokalnych. Stwierdzono potrzebę szczegółowego planowania tego procesu, szerokiej partycypacji społecznej, integracji działań wszystkich uczestników, wypracowanie modeli organizacji i zarządzania oraz sposobów finansowania.

Bardzo istotnym założeniem, które pojawiło się w projekcie Ustawy, a które w rezultacie okazało się przeszkodą nie do pokonania w jej uchwaleniu, było wskazanie konieczności znacznego wsparcia finansowego rewitalizacji ze środków publicznych na poziomie krajowym. Jak wspomniano na początku niniejszego rozdziału, wsparcie takie jest udzielane przez rząd dla działań rewitalizacyjnych dotyczących zarówno zdegradowanych obszarów miejskich, jak i obszarów poprzemysłowych, w wielu krajach Europy Zachodniej (np. Niemcy, Wielka Brytania, Hiszpania, Francja, Holandia). W 2004 r. pomysł wycofania wsparcia rządowego dla rewitalizacji w Niemczech wzbudził żywy sprzeciw władz miejskich i firm operatorskich prowadzących rewitalizację. $\mathrm{Na}$ zwołanej w Berlinie w czerwcu 2004 r. konferencji pod znamiennym tytułem Zurück in die Stadt ( $Z$ powrotem w mieście), w której wzięli udział przedstawiciele rządu i władz lokalnych reprezentujących głównie miasta landów wschodnich Niemiec, strona samorządowa stwierdziła jednogłośnie, iż w sytuacji wycofania dotacji rządowych władze lokalne nie będą w stanie podołać finansowaniu zadań związanych z rewitalizacją.

Kolejną ważną kwestią, jaką rozstrzygać miała ustawa o rewitalizacji, było opracowanie konstrukcji organizacyjno-prawnej dla podmiotu zarządzającego rewitalizacją. Jest to proces długotrwały (programy obejmują często okres od kilkunastu do trzydziestu lat), w związku z czym istotnym zagrożeniem dla jego stabilności jest kwestia uniezależnienia przeprowadzanych działań od politycznych fluktuacji i zmian wynikających z kadencyjności organów samorządu lokalnego. Zgodnie z projektem ustawy rolę związaną ze sporządzaniem, organizacją i prowadzeniem programu rewitalizacji miałby pełnić pełnomocnik ds. rewitalizacji - osoba fizyczna lub prawna, powołana przez zarząd gminy. Podmiot wdrażający program rewitalizacji musiałby dysponować szerokim wachlarzem wiedzy, związanej z koordynacją działań publicznych i prywatnych, zarządzania finansami pochodzącymi $\mathrm{z}$ wielu źródeł oraz umiejętnością komunikacji społecznej i mediacji. Program rewitalizacji miałby być opracowywany i uchwalany równolegle $\mathrm{z}$ projektem miejscowego planu zagospodarowania przestrzennego (lub jego zmiany) dla obszaru rewitalizacji.

\footnotetext{
${ }^{11}$ Urząd Mieszkalnictwa i Rozwoju Miast, projekt ustawy o rewitalizacji, Warszawa 2003.
} 
W zakresie finansowania programów rewitalizacji Projekt przewidywał stworzenie trzech narzędzi finansowania:

- gminny fundusz rewitalizacji,

- wojewódzki fundusz rewitalizacji oraz

- specjalny kredyt, nazwany sanacyjnym ${ }^{12}$.

\subsection{Nowe propozycje regulacji ustawowych $w$ zakresie rewitalizacji}

Potrzeba wprowadzenia ustawowych regulacji dotyczących procesu rewitalizacji jest nadal artykułowana zarówno przez specjalistów zajmujących się tą dziedziną, jak i władze lokalne.

W 2006 r. w Urzędzie Miasta Łodzi podjęto inicjatywę sformułowania nowych propozycji do projektu ustawy o rewitalizacji. W prace zaangażowany był zespół ekspertów reprezentujący Uniwersytet Łódzki i Politechnikę Łódzką oraz przedstawiciele zainteresowanych wydziałów Urzędu Miasta Łodzi. Prace koordynował Włodzimierz Tomaszewski - Wiceprezydent Miasta Łodzi, a zarazem Pełnomocnik ds. Rewitalizacji UMŁ.

Za kwestie podstawowej wagi w przyszłym dokumencie ustawowym dotyczącym rewitalizacji uznano następujące problemy:

1. Rewitalizacja powinna być celem publicznym.

2. Ustalenie relacji program rewitalizacji - plan miejscowy. Stwierdzono, że plany miejscowe „usztywniają" lokalne projekty rewitalizacji, są mało elastyczne, w związku z czym należałoby rozważyć, czy możliwa i uzasadniona byłaby „deregulacja” dla obszarów objętych programem rewitalizacji, np. poprzez zastosowanie zasady wyłączenia w pewnym zakresie $\mathrm{z}$ obowiązujących ustaleń planów miejscowych. Plan miejscowy obejmowałby w takich przypadkach ustalenia dla zadań priorytetowych $\mathrm{w}$ obszarze rewitalizacji - komunikacji i przestrzeni publicznych, pozostałe tereny w obszarze rewitalizacji byłyby z planu ,wyłączone", objęte jedynie zapisami regulującymi działania niedopuszczalne, co znacznie zwiększyłoby elastyczność możliwych działań inwestycyjnych.

3. Konieczność „,zamrożenia” cen nieruchomości w rewitalizowanych obszarach, aby uniknąć spekulacji.

4. Konieczność uruchomienia dodatkowych programów społecznych w ramach programów rewitalizacji, aby mieszkańcy byli w stanie ponieść koszty utrzymania rewitalizowanych zasobów.

5. Potrzeba określenia zasady koncentracji działań i środków w ramach programów rewitalizacji dla osiągnięcia efektu „kuli śniegowej” i „samonapędzania się" rewitalizacji.

${ }^{12}$ Podręcznik rewitalizacji. Zasady, procedury i metody działania wspótczesnych procesów rewitalizacji, Warszawa 2003, s. 37. 
6. Potrzeba uregulowania problemów własnościowych - utworzenie funduszu rekompensat oraz ustanowienie okresu, w jakim właściciele nieruchomości mogą je odzyskać - aby uniknąć zagrożenia nagłego „odnalezienia się” właściciela, w sytuacji, kiedy gmina poniesie koszty rewitalizacji nieruchomości o niewyjaśnionym stanie własności.

7. Konieczność wprowadzenia zmian w ustawach „powiązanych” - np. prawo eksmisji w obszarze rewitalizowanym, zapisy o najemcach, którzy nie wywiązują się z należności czynszowych; podatek od nieruchomości powinien być powiązany z jej wartością.

8. Operator rewitalizacji powinien być niezależnym podmiotem, który z realizowania programu będzie miał konkretny zysk - dopiero wówczas program rewitalizacji ma szansę na skuteczne wdrażanie ${ }^{13}$.

Wypracowane w wyniku współpracy pomiędzy przedstawicielami władz naukowych i kół samorządowych szczegółowe propozycje do ustawy o rewitalizacji zostały przedstawione następnie do konsultacji w Unii Metropolii Polskich, nie udało się jednak doprowadzić do wprowadzenia propozycji ustawy pod dyskusję Sejmu.

Krzysztof Skalski, na bazie wniosków z doświadczeń polskich programów rewitalizacji ostatnich kilkunastu lat, przedstawia propozycje wprowadzenia nowych narzędzi urbanistyki operacyjnej, wspierających przygotowanie i wdrażanie programów rewitalizacji. Bez tych narzędzi LPR też będą realizowane, ale mniej efektywnie, a ich zastosowanie przyczyniłoby się do:

- Powiększenia zasięgu funkcjonalnego i kompleksowości programów rewitalizacji.

- Uniknięcia nieuzasadnionej spekulacji terenami, która w innych krajach demokratycznych jest piętnowana przez prawo karne (jako przestępstwo wynikające z tzw. „wczesnego poinformowania”).

- Utrzymania ludności słabej finansowo w rewitalizowanych dzielnicach miejskich - w imię solidarności społecznej oraz unikania peryferyzacji i wykluczenia społecznego.

Propozycje do legislacji dotyczyły przede wszystkim:

- Potrzeby poszerzenia prawa pierwokupu komunalnego, które powinno obejmować wszystkie nieruchomości w obszarze objętym LPR, bez względu na rodzaj własności - w celu umożliwienia prowadzenia konsekwentnej polityki gruntowej na potrzeby społeczności lokalnej (parkingi, pasaże, zagospodarowanie wnętrz kwartałów zabudowy).

- Konieczności uznania LPR za cel publiczny.

- Stworzenia: Strefy Inwestowania Uzgodnionego, Interwencji Gruntowej.

${ }^{13}$ Zapis dyskusji nad propozycjami zmian w projekcie ustawy o rewitalizacji w UMŁ, 19.04.2006 r. 
- Wprowadzenia ,premii remontowych”.

- Konieczności reformy czynszów i dodatków mieszkaniowych.

- Wprowadzenia możliwości uchwalania regionalnych podatków na rewitalizację.

- Stworzenia pojęcia ,przestępstwa wynikającego z wczesnego informowania" - dla zapobieżenia przejęciu przez osoby fizyczne dochodu należnego poprzedniemu właścicielowi, czyli gminie ${ }^{14}$.

Przedstawione wyżej propozycje, zarówno ministerialna, jak i opracowywane przez władze lokalne oraz specjalistów zajmujących się rewitalizacją pozostają do chwili obecnej nadal jedynie w sferze projektów. Należy mieć jednak nadzieję, że prowadzone $\mathrm{w}$ dalszym ciągu prace zarówno na szczeblu ministerialnym, jak i w ramach stowarzyszeń zawodowych, w zakresie stworzenia ustawy o planowaniu przestrzennym dostosowanej do potrzeb zintegrowanego zarządzania miastami, będą również uwzględniały problematykę rewitalizacji i odnowy miejskiej jako elementu zrównoważonego rozwoju miast.

\footnotetext{
${ }^{14}$ K. Skalski, Lokalne Programy Rewitalizacji na lata 2008-2013. Wybrane propozycje modyfikacji legislacyjnych, „Urbanista” 2008, nr 6 (66), s. 13-15.
} 